\title{
Production of Ceiling Board from Piliostigma thonningii using Styrofoam Adhesive as Binder
}

\author{
Ibrahim Shuaibu Muhammad ${ }^{1}$, Usman Aliyu El-Nafaty ${ }^{2}$, Surajudeen Abdulsalam ${ }^{2}$
}

${ }^{1}$ Abubuakar Tatari Ali Polytechnic

P. M. B. 0094, Bauchi, 740272, Nigeria

${ }^{2}$ Abubakar Tafawa Balewa University

P. M. B. 0248, Bauchi, 740272, Nigeria

DOI: $10.22178 /$ pos. $45-6$

LCC Subject Category: TH1-9745

Received 26.03.2019

Accepted 27.04.2019

Published online 30.04.2019

Corresponding Author:

Ibrahim Shuaibu Muhammad

shuaibudogo70@gmail.com

(C) 2019 The Authors. This article

is licensed under a Creative Commons

Attribution 4.0 License @) (1)

\begin{abstract}
The use of synthetic fibres resulted in environmental degradation and the growing interests towards the utilisation of readily available agricultural fibres as a potential replacement for synthetic fibres. This research aims to produce a ceiling board composite from piliostigma thonningii particulate using styrofoam adhesive binder. The board was produced from the readily available materials leading to the low cost of production. The composition has a formulation of fibre/binder mixing ratios $(2: 1,1: 1,1: 2 \mathrm{w}: \mathrm{w})$, pressures of $\left(100,300,500 \mathrm{~kg} / \mathrm{m}^{2}\right)$ and temperatures of $\left(30,65,100{ }^{\circ} \mathrm{C}\right)$ respectively. The process was successfully modelled and optimized using a Box-Behnken design method. The optimal conditions for the piliostigma thonningii board were found to be fibre/binder mixing ratio of $1: 1 \mathrm{w}: \mathrm{w}$, pressure of $500 \mathrm{~kg} / \mathrm{m}^{2}$ and temperature of $92{ }^{\circ} \mathrm{C}$ yielded response values of density $\left(151.5 \mathrm{~kg} / \mathrm{m}^{3}\right)$, water absorption $(9.04 \%)$, tensile strength $\left(16.9 \mathrm{~N} / \mathrm{m}^{2}\right)$, thermal conductivity $(0.11 \mathrm{~W} / \mathrm{mK})$. Hence the board has greater insulating properties and good potential to be used as a ceiling board.
\end{abstract}

Keywords: production; piliostigma thonningii; ceiling board.

\section{INTRODUCTION}

Composite is a combination of two materials in which one of the material, called the reinforcing phase is embedded in the other material called the matrix phase [17].

Ceiling board is composite products manufactured from particles of wood or other cellulosic fibre materials using adhesive as a binder.

The important role of ceiling board:

- creates a perfect ambience that can improve the acoustical system;

- use as insulators and reduces heat transfer into the building;

- adds value to the existing architecture of buildings;

- use in holding up building materials.

The rising concern towards the environmental issues on the one hand and the need for more versatile polymer-based materials, on the other hand, have led to increasing interest in polymers filled with natural lignocellulosic agro fibre. The Lignocellulosic fibres are low-cost raw material, abundant in nature and renewable. Besides that, the less abrasive nature of the lignocellulosic fibres offered a friendlier processing environment and offered good thermal and insulating properties, easily recyclable and biodegradable especially when used as reinforcement in a biopolymer.

Natural reinforcements have advantages over reinforcements as a result of the natural alignment of carbon-carbon bonds and also significant strength, stiffness [12], low density, low cost and bio-degradability they offer.

Piliostigma thonningii is a woody plant found grows in savannah regions that are moist and wooded grass land in low to medium altitudes; it is widely distributed in Africa [10]. The English name is monkey bread or camel's foot. In Nigeria, the plant grows abundantly as a wild, uncultivated tree.

Piliostigma thonningii is a plant which contents $85 \%$ lignocellulosic fibre as shown in Table 1; the lignocellulosic fibres have the potential to be 
an effective reinforcement in thermoplastics and thermosetting materials [5].

Table 1 - The basic chemical component and compositions of lignocellulosic fibres in Piliostigma thonningii plant

\begin{tabular}{|l|c|}
\hline Component Value & Percentage (\%) composition \\
\hline Moisture & 6.71 \\
\hline Ash & 3.50 \\
\hline Protein & 3.37 \\
\hline Cellulosic Fibres & \\
Cellulose & 40 lignocellulose \\
Hemi - Cellulose & 25 lignocellulose \\
lignin & 20 lignocellulose \\
\hline Lipid & 1.42 \\
\hline Acid value & $13.73 \pm 1.40$ \\
\hline Iodine vale & $50.76 \pm 1.80$ \\
\hline Colour & Pinkish to dark brown \\
\hline
\end{tabular}

Source: [10]

The styrofoam is an environmental unfriendly solid waste styrene; non-biodegradable materials and readily soluble in acetone but insoluble in water [1]. However, it is a very lightweight, plastic material, formed when air (or other "blowing agents") blown through molten polystyrene as it is extruded to foam up and produces the light foamy material known as "Styrofoam".

Styrofoams are normally thrown away after been used during ceremonies, occasions or after other materials been packaged were removed.

This paper aims at the production, optimisation and evaluation of the fundamental properties of ceiling board composite from piliostigma thonningii that can have a potential application of low thermal conductivity and also help to preserve the environment by reducing the indiscriminate littering of Styrofoam.

\section{MATERIALS AND METHODS}

Materials. The major raw materials for this work are the stem fibres of piliostigma thonningii. Other materials include styrofoam, unsaturated polyester resin, sodium hydroxide $(\mathrm{NaOH})$, gasoline, distilled water.

Preparation of styrofoam adhesive. The styrofoam was cleaned and made free of dirt. Forty grams (40 g) of styrofoam was dissolved in $120 \mathrm{ml}$ of gasoline and stirred to enhance the dissolution of the styrofoam. In this research, the $60 \%$ unsatu- rated polyester resin was mixed with $40 \%$ dissolved styrofoam adhesive. The formulated solution was stirred twice daily for a week until the formulated adhesive reaches homogeneity and stabilisation.

Preparation Piliostigma thonningii into wood particles. The piliostigma thonningii stems were collected and washed thoroughly with clean water to remove any unwanted particles. The cleaned piliostigma thonningii (stem) were reduced into chips, then mercerised using $5 \% \mathrm{w} / \mathrm{v}$ sodium hydroxide $(\mathrm{NaOH})$ solution at room temperature for 24 hours. The piliostigma thonningii (chips) were thoroughly washed in fresh tap water and air dried. The dried chips were ground into small particle sizes. The sieve analysis of particles was carried out by BS 1377-3:2018 [6].

Sample Preparation. Three numbers of moulds of $0.15 \mathrm{~m}$ by $0.15 \mathrm{~m}$ were constructed with a thickness of $0.10 \mathrm{~m}$. The required quantity of piliostigma thonningii particle sizes was mixed with prepared styrofoam adhesive ratios and compounded into the mould. Pressure and heat were applied for crosslinking and hardening the boards. The board's sample was cut and prepared for characterisation tests subjected to Density, Water absorption, Tensile strength and Thermal conductivity.

Experimental Design. Equation 1 was used in determining the number of experimental runs for the design.

$$
N=k^{2}+k+C p
$$

where $k$ is the number of factors, $C p$ is the number of replication.

Minitab 17 software Design Expert was used, and the process was successfully modelled and optimised using a Box-Behnken design method.

The composition has a formulation of fibre/binder mixing ratios (2:1, 1:1, 1:2 w:w), pressures of $\left(100,300,500 \mathrm{~kg} / \mathrm{m}^{2}\right)$ and temperatures of $\left(30^{\circ} \mathrm{C}, 65^{\circ} \mathrm{C}, 100^{\circ} \mathrm{C}\right)$ respectively.

The Analysis of variance (ANOVA) was also used to check the adequacy of the model for the experimental outputs (responses) at nearly all conditions.

Determination of density. The densities of the boards were determined by the ASTM C30310(2016)e1 (Standard Test Method for Dimen- 
sions and Density of Preformed Block and Board-Type Thermal Insulation) [3]. From each of the boards prepared, three (3) sample specimens were cut for the test, and the volume of each specimen was calculated using equation as follows:

$$
\text { Volume, } \mathrm{m}^{3}=l \times w \times \Delta x
$$

The mass of each specimen was determined using a digital weighing balance and the mass recorded. The density of each specimen is determined using equation (2) based on ASTM (3):

$$
\text { Density, } \frac{\mathrm{kg}}{\mathrm{m}^{3}}=\frac{\text { weight of the composite }}{\text { volume of the composite }}
$$

Determination of water absorption. The water absorption test was conducted according to ASTM D1037-12 [2]. The specimens have a dimension of $0.14 \mathrm{~m} \times 0.14 \mathrm{~m} \times 0.1 \mathrm{~m}$ used in the determination of the density were used since their masses and volume were recorded. Each specimen was immersed in water at ambient temperature of 24 hours until equilibrium. The specimens were removed and patted dry with a towel (lint free) and then weighed using a digital weighing balance. The dry weight before immersion $\left(\mathrm{w}_{1}\right)$ and the weight after immersion $\left(\mathrm{w}_{2}\right)$ were noted. The water absorption was expressed as the percentage increase in volume based on the volume before immersion. Equation (4) was applied to determine the percentage of water absorption by ASTM D570-98(2018) [4]:

$$
W_{A}=\frac{w_{2}-w_{1}}{w_{1}} \times 100
$$

where $w_{1}$ is the weight of the sample before immersion in water; $w_{2}$ the weight of the sample after immersion in water.

Determination of tensile strength. Monsanto Tensometer machine is used to determine the tensile strength of the ceiling board composites of various compositions as specified by the American society for testing and material. The sample dimensions of $60 \times 8 \times 5 \mathrm{~mm}$ with dumb bell shape outside the gauge length. The dumb bell part clamped to jaws of the machine and the extension produces within the gauge span of the specimen. The evaluation of ulthe timate tensile strength (UTS) can be determined using equation (5).

$$
\mathrm{UTS}=\frac{\text { Average force }}{\text { cross section area }}
$$

Determination of thermal conductivity. The thermal conductivity of the boards was determined by [2]. The equipment used for the test was Armfield HT10XC Heat Transfer Service Unit and HT11C Computer Compatible Linear Heat Conduction Accessory. From each of the boards, four (4) specimens were cut in the form of a disc of diameter (d) $25 \times 1 \mathrm{~mm}$ and the thickness $(x)$ was measured and recorded. A specimen was clamped tightly in between two faces of heated and cooled brass sections, the heater voltage $(V)$ was set to 10 volts, and the heater current (1) was read from the console and recorded. After HT11C was stabilized, the temperatures $T_{1}, T_{2}, T_{3}$, $T_{7}$, and $T_{8}$ were also read and recorded from the console display. Where $T_{1}, T_{2}$ and $T_{8}$ are the thermocouples connected to the heating section of the instrument and $T_{6}, T_{7}$ and $T_{8}$ are those connected to the cold section of the instrument. The thermal conductivity $(\mathrm{k})$ of a material was determined from equation (6)-(8):

$$
\begin{aligned}
& k=\frac{\text { Heat } \times \text { Distance }}{\text { Area } \times \text { Temperaturegradient }} . \\
& \Delta T=T_{\text {hot }}-T_{\text {cold }}
\end{aligned}
$$

where $T_{\text {hot }}=T_{2-} \frac{\left(T_{2}-T_{3}\right)}{2}, T_{\text {cold }}=T_{6-} \frac{\left(T_{6}-T_{7}\right)}{2}$.

Apply Fourier rate equation to determine the thermal conductivity (k) of a specimen (8):

$$
Q=-k A \frac{\Delta T}{\Delta x}\left(\frac{\mathrm{W}}{\mathrm{mK}}\right)
$$

\section{RESULTS AND DISCUSSION}

Various experiments were determined; the results of the experiment obtained were subjected to Response Surface Regression analysis using the Statistical package Minitab 17. The independent variables are piliostigma thonningii fibre / styrofoam adhesive ratio, pressure, and temperature. The density, water absorption, tensile strength and thermal conductivity test results measured as output parameters (responses) for the 15 runs are given in Table 2. 
Table 2 - The independent variables and responses

\begin{tabular}{|l|c|c|c|c|c|c|c|}
\hline Run & $\begin{array}{c}\text { Piliostigma } \\
\text { thonningii / } \\
\text { Styrofoam Adhesive } \\
(\mathrm{w}: \mathrm{w})\end{array}$ & $\begin{array}{c}\text { Pressure } \\
\left(\mathrm{kg} / \mathrm{m}^{2}\right)\end{array}$ & $\begin{array}{c}\text { Temperature } \\
\left({ }^{\circ} \mathrm{C}\right)\end{array}$ & $\begin{array}{c}\text { Density } \\
\left(\mathrm{kg} / \mathrm{m}^{3}\right)\end{array}$ & $\begin{array}{c}\text { Water } \\
\text { Absorption } \\
(\%)\end{array}$ & $\begin{array}{c}\text { Tensile } \\
\text { strength } \\
\left(\mathrm{N} / \mathrm{m}^{2}\right)\end{array}$ & $\begin{array}{c}\text { Thermal } \\
\text { conductivity } \\
(\mathrm{W} / \mathrm{mK})\end{array}$ \\
\hline 1 & $1: 2$ & 100 & 65 & 202.47 & 0.83 & 15.94 & 0.25 \\
\hline 2 & $2: 1$ & 100 & 65 & 152.35 & 28.63 & 10.34 & 0.10 \\
\hline 3 & $1: 2$ & 500 & 65 & 201.99 & 0.68 & 14.20 & 0.23 \\
\hline 4 & $2: 1$ & 500 & 65 & 145.85 & 25.21 & 19.32 & 0.06 \\
\hline 5 & $1: 2$ & 300 & 30 & 218.25 & 0.78 & 13.84 & 0.23 \\
\hline 6 & $2: 1$ & 300 & 30 & 140.31 & 27.30 & 9.81 & 0.12 \\
\hline 7 & $1: 2$ & 300 & 100 & 185.43 & 4.26 & 15.02 & 0.26 \\
\hline 8 & $2: 1$ & 300 & 100 & 133.78 & 15.88 & 12.02 & 0.06 \\
\hline 9 & $1: 1$ & 100 & 30 & 161.67 & 15.67 & 13.82 & 0.14 \\
\hline 10 & $1: 1$ & 500 & 30 & 158.34 & 13.74 & 12.58 & 0.12 \\
\hline 12 & $1: 1$ & 100 & 30 & 149.72 & 15.54 & 14.50 & 0.09 \\
\hline 13 & $1: 1$ & 500 & 65 & 149.22 & 10.55 & 17.82 & 0.08 \\
\hline 14 & $1: 1$ & 300 & 65 & 130.79 & 10.95 & 10.87 & 0.08 \\
\hline 15 & $1: 1$ & 300 & 65 & 131.26 & 10.95 & 10.85 & 0.08 \\
\hline
\end{tabular}

The analysis of variance (ANOVA) technique was used to check the adequacy of the developed models at $95 \%$ confidence level for the model to satisfy the adequacy conditions in non-linear form.

Table 3 shows the ANOVA results for density, where the model is significant at $1 \%$ level with a p-value of 0.000 . The main terms: w:w and temperature are both significant at $1 \%$ level with p- values of 0.000 and 0.006 respectively while only pressure is not significant. The Square terms indicated that all the three independent variables are significant at $1 \%$ level. While only interaction between w:w and pressure are significant at $5 \%$ level with a p-value of 0.039 . The R-squared value for the model is $99.05 \%$ which shows that the $\mathrm{R}$-squared is enough, explained adequately for the model to be considered.

Table 3 - ANOVA result for model representing density

\begin{tabular}{|l|c|c|c|c|c|}
\hline Source & DF & Adj SS & Adj MS & F-value & P-value \\
\hline Model & 9 & 11574.2 & 1286.02 & 57.84 & 0.000 \\
\hline Linear & $\mathbf{3}$ & $\mathbf{7 4 2 4 . 5}$ & $\mathbf{2 4 7 4 . 8 4}$ & $\mathbf{1 1 1 . 3 1}$ & $\mathbf{0 . 0 0 0}$ \\
\hline w:w & 1 & 6953.5 & 6953.54 & 312.75 & 0.000 \\
\hline Pressure & 1 & 14.6 & 14.62 & 0.66 & 0.454 \\
\hline Temperature & 1 & 456.4 & 456.37 & 20.53 & 0.006 \\
\hline Square & $\mathbf{3}$ & $\mathbf{3 9 6 5 . 9}$ & $\mathbf{1 3 2 1 . 9 6}$ & $\mathbf{5 9 . 4 6}$ & $\mathbf{0 . 0 0 0}$ \\
\hline w:w ${ }^{*}$ w:w & 1 & 3252.2 & 3252.18 & 146.27 & 0.000 \\
\hline Pressure ${ }^{\text {Pressure }}$ & 1 & 827.93 & 827.93 & 37.24 & 0.002 \\
\hline Temperature ${ }^{T}$ Temperature & 1 & 282.70 & 20.17 & 12.72 & 0.016 \\
\hline 2-way interaction & $\mathbf{3}$ & $\mathbf{1 8 3 . 8}$ & $\mathbf{6 1 . 2 7}$ & $\mathbf{2 . 7 6}$ & $\mathbf{0 . 1 5 2}$ \\
\hline w:W ${ }^{*}$ Pressure & 1 & 9.0 & 9.04 & 0.41 & 0.552 \\
\hline w:w ${ }^{T}$ Temperature & 1 & 172.8 & 172.76 & 7.77 & 0.039 \\
\hline Pressure*Temperature & 1 & 2.00 & 2.00 & 0.09 & 0.776 \\
\hline Residual & 5 & 111.2 & 22.23 & & \\
\hline Lack of fit & $\mathbf{3}$ & $\mathbf{1 1 1 . 2}$ & $\mathbf{3 7 . 0 2}$ & $\mathbf{6 3 8 . 8 5}$ & $\mathbf{0 . 0 0 2}$ \\
\hline Pure error & $\mathbf{2}$ & $\mathbf{0 . 0 0}$ & $\mathbf{0 . 0 0}$ & & \\
\hline Total & 14 & 11685.4 & & & \\
\hline
\end{tabular}

Model summary

\begin{tabular}{|c|c|c|c|}
\hline S & R-sq, \% & R-sq(adj), \% & R-sq(pred), \% \\
\hline 4.71525 & 99.05 & 97.34 & 84.79 \\
\hline
\end{tabular}


Water Absorption. The results in Table 4 shows that the model is significant at $1 \%$ level with a pvalue of 0.002 . The lack of fits test shows significance at $1 \%$ level, which suggests that higher order terms can still be incorporated into the model. The Main terms show that $\mathrm{w}: \mathrm{w}$ is significant with a p-value of 0.000 , while pressure and temperature are not significant.

Table 4 - ANOVA result for water absorption

\begin{tabular}{|l|c|c|c|c|c|}
\hline \multicolumn{1}{|c|}{ Source } & DF & Adj SS & Adj MS & F-value & P-value \\
\hline Model & 9 & 1134.59 & 1350.8 & 21.60 & 0.002 \\
\hline Linear & $\mathbf{3}$ & $\mathbf{1 0 5 2 . 6 7}$ & $\mathbf{2 6 . 0 7}$ & $\mathbf{6 0 . 1 1}$ & $\mathbf{0 . 0 0 0}$ \\
\hline w:w & 1 & 1023.07 & 1023.0 & 175.25 & 0.000 \\
\hline Pressure & 1 & 13.75 & 13.75 & 2.36 & 0.185 \\
\hline Temperature & 1 & 15.85 & 15.85 & 2.71 & 0.160 \\
\hline Square & $\mathbf{3}$ & $\mathbf{2 1 . 4 2}$ & $\mathbf{7 . 1 4}$ & $\mathbf{1 . 2 2}$ & $\mathbf{0 . 3 9 3}$ \\
\hline w:w ${ }^{*}$ w:w & 1 & 1.05 & 1.05 & 0.18 & 0.690 \\
\hline Pressure *Pressure & 1 & 20.47 & 20.47 & 3.51 & 0.120 \\
\hline Temperature *Temperature & 1 & 1.20 & 1.20 & 0.21 & 0.669 \\
\hline 2-way interaction & $\mathbf{3}$ & $\mathbf{6 0 . 5 0}$ & $\mathbf{2 0 . 1 7}$ & $\mathbf{3 . 4 5}$ & $\mathbf{0 . 1 0 8}$ \\
\hline w:w*Pressure & 1 & 2.68 & 2.68 & 0.46 & 0.528 \\
\hline w:w ${ }^{*}$ Temperature & 1 & 55.48 & 55.48 & 9.50 & 0.027 \\
\hline Pressure *Temperature & 1 & 2.34 & 2.34 & 0.40 & 0.554 \\
\hline Residual & 5 & 29.19 & 5.84 & & \\
\hline Lack of fit & $\mathbf{3}$ & $\mathbf{2 9 . 1 9}$ & $\mathbf{9 . 7 3}$ & $\mathbf{3 4 5 0 5 3}$ & $\mathbf{0 . 0 0 0}$ \\
\hline Pure error & $\mathbf{2}$ & $\mathbf{0 . 0 0}$ & $\mathbf{0 . 0 0}$ & & \\
\hline Total & 14 & 1163.78 & & & \\
\hline
\end{tabular}

Model summary

\begin{tabular}{|c|c|c|c|}
\hline S & R-sq, \% & R-sq(adj), \% & R-sq(pred), \% \\
\hline 2.41614 & 97.49 & 92.98 & 59.87 \\
\hline
\end{tabular}

For the Square terms show that all the square factors for the three variables are not significant at $5 \%$ level. In the interactions, it is only the interactions between $\mathrm{w}: \mathrm{w}$ and temperature that shows significance at $5 \%$ level with a p-value of 0.027 . The other interactions are not significant. The R-squared value of the model is $97.49 \%$; this implies that R-squared is enough, which explained adequately for the model to be considered

Tensile strength. Table 5; shows the ANOVA result for Tensile strength. The result shows that the model is significant at $5 \%$ level with a p-value of 0.037 . This is enough even though the lack of fit suggests the addition of higher-order variables (i.e. significant at 1\%). The variables in the main model terms show that: Pressure and Temperature are relatively significant at $10 \%$ with pvalues of 0.073 and 0.065 respectively, while $\mathrm{w}: \mathrm{w}$ is not significant. The square terms indicated only pressure is significant at $1 \%$ per cent level with a p-value of 0.008 , while others are not significant. The interaction between $\mathrm{w}: \mathrm{w}$ and pressure are significant at $5 \%$ level with a p- value of 0.014 . The other interactions are not significant. The R-squared value for the model is $90.87 \%$, which reveals that the independent variables account for $90.87 \%$ of the variation in tensile strength.

Thermal Conductivity. The results in Table 6 shows that the model is significant at $1 \%$ level with a p-value of 0.000 . The lack of fits test shows significance at $1 \%$ level, which suggests that higher order terms can still be incorporated into the model and the main term: $w: w$ is significant with a p-value of 0.000 , while pressure is relatively significant at $10 \%$ level with a p-value of 0.069 and temperature is significant at $5 \%$ level with a p-value of 0.017 while the square term show that; $\mathrm{w}: \mathrm{w}{ }^{*} \mathrm{w}: \mathrm{w}$ is significant at $1 \%$ level, temperature is significant at $5 \%$ level, pressure is not significant and the interactions indicated that only the interactions between $\mathrm{w}: \mathrm{w}$ and temperature is significance at $1 \%$ level with a p-value of 0.008 . The other interactions are not significant. However, the R-squared of $99.02 \%$ has explained enough variations for the model to be considered. 
Table 5 - ANOVA result for model representing tensile strength

\begin{tabular}{|l|c|c|c|c|c|}
\hline \multicolumn{1}{|c|}{ Source } & DF & Adj SS & Adj MS & F-value & P-value \\
\hline Model & 9 & 97.480 & 10.8311 & 5.53 & 0.037 \\
\hline Linear & $\mathbf{3}$ & $\mathbf{2 7 . 0 7 8}$ & $\mathbf{9 . 0 2 5 9}$ & $\mathbf{4 . 6 1}$ & $\mathbf{0 . 0 6 7}$ \\
\hline w:w & 1 & 6.230 & 6.2304 & 3.18 & 0.135 \\
\hline Pressure & 1 & 10.013 & 10.0128 & 5.11 & 0.073 \\
\hline Temperature & 1 & 10.835 & 10.8345 & 5.53 & 0.065 \\
\hline Square & $\mathbf{3}$ & $\mathbf{3 8 . 5 7 0}$ & $\mathbf{1 2 . 8 5 6 7}$ & $\mathbf{6 . 5 6}$ & $\mathbf{0 . 0 3 5}$ \\
\hline w:W ${ }^{*}$ w:w & 1 & 4.327 & 4.3267 & 2.21 & 0.197 \\
\hline Pressure * Pressure & 1 & 35.255 & 35.2545 & 18.00 & 0.008 \\
\hline Temperature * Temperature & 1 & 1.914 & 1.9141 & 0.98 & 0.368 \\
\hline 2-way interaction & $\mathbf{3}$ & $\mathbf{3 1 . 8 3 2}$ & $\mathbf{1 0 . 6 1 0 6}$ & $\mathbf{5 . 4 2}$ & $\mathbf{0 . 0 5 0}$ \\
\hline w:w ${ }^{*}$ Pressure & 1 & 26.368 & 26.3682 & 13.46 & 0.014 \\
\hline w:W ${ }^{*}$ Temperature & 1 & 0.265 & 0.2652 & 0.14 & 0.728 \\
\hline Pressure *Temperature & 1 & 5.198 & 5.1984 & 2.65 & 0.164 \\
\hline Residual & 5 & 9.794 & 1.9588 & & \\
\hline Lack of fit & $\mathbf{3}$ & $\mathbf{9 . 7 9 3}$ & $\mathbf{3 . 2 6 4 4}$ & $\mathbf{8 1 6 0 . 9 4}$ & $\mathbf{0 . 0 0 0}$ \\
\hline Pure error & $\mathbf{2}$ & $\mathbf{0 . 0 0 1}$ & $\mathbf{0 . 0 0 0 4}$ & & \\
\hline Total & 14 & 107.27 & & & \\
\hline
\end{tabular}

Model summary

\begin{tabular}{|c|c|c|c|}
\hline S & R-sq, $\%$ & R-sq(adj), $\%$ & R-sq(pred), $\%$ \\
\hline 1.39957 & 90.87 & 74.44 & 0.00 \\
\hline
\end{tabular}

Table 6 - ANOVA result for model representing thermal conductivity

\begin{tabular}{|l|c|c|c|c|c|}
\hline \multicolumn{1}{|c|}{ Source } & DF & Adj SS & Adj MS & F-value & P-value \\
\hline Model & 9 & 0.07137 & 0.00793 & 56.37 & 0.000 \\
\hline Linear & $\mathbf{3}$ & $\mathbf{0 . 0 5 1 5 4}$ & $\mathbf{0 . 0 1 7 1 8}$ & $\mathbf{1 2 2 . 1 3}$ & $\mathbf{0 . 0 0 0}$ \\
\hline w:w & 1 & 0.04904 & 0.04904 & 348.60 & 0.000 \\
\hline Pressure & 1 & 0.00075 & 0.00075 & 5.34 & 0.069 \\
\hline Temperature & 1 & 0.00175 & 0.00175 & 12.43 & 0.017 \\
\hline Square & $\mathbf{3}$ & $\mathbf{0 . 0 1 7 2 6}$ & $\mathbf{0 . 0 0 5 7 5}$ & $\mathbf{4 0 . 9 0}$ & $\mathbf{0 . 0 0 1}$ \\
\hline w:w ${ }^{*}$ w:w & 1 & 0.01635 & 0.01635 & 116.25 & 0.000 \\
\hline Pressure *Pressure & 1 & 0.00041 & 0.00041 & 2.96 & 0.146 \\
\hline Temperature *Temperature & 1 & 0.00149 & 0.00149 & 10.61 & 0.023 \\
\hline 2-way interaction & $\mathbf{3}$ & $\mathbf{0 . 0 0 2 5 7}$ & $\mathbf{0 . 0 0 0 8 5}$ & $\mathbf{6 . 1 0}$ & $\mathbf{0 . 0 4 0}$ \\
\hline w:W ${ }^{*}$ Pressure & 1 & 0.00004 & 0.00004 & 0.33 & 0.593 \\
\hline w:W ${ }^{*}$ Temperature & 1 & 0.00252 & 0.00252 & 17.96 & 0.008 \\
\hline pressure *Temperature & 1 & 0.00000 & 0.00000 & 0.00 & 0.964 \\
\hline Residual & 5 & 0.00070 & 0.00014 & & \\
\hline Lack of fit & $\mathbf{3}$ & $\mathbf{0 . 0 0 0 7 0}$ & $\mathbf{0 . 0 0 0 2 3}$ & $\mathbf{5 7 1 3 7 0 . 7}$ & $\mathbf{0 . 0 0 0}$ \\
\hline Pure error & $\mathbf{2}$ & $\mathbf{0 . 0 0 0}$ & $\mathbf{0 . 0 0 0}$ & & \\
\hline Total & 14 & 0.07207 & & & \\
\hline
\end{tabular}

Model summary

\begin{tabular}{|c|c|c|c|}
\hline S & R-sq, \% & R-sq(adj), \% & R-sq(pred), \% \\
\hline 0.01186 & 99.02 & 97.27 & 84.39 \\
\hline
\end{tabular}


Optimisation of Independent. The experimental parameters that produce maximum or minimum values of responses depend on optimisation cri- teria. Table 7 shows the best responses optimal results solution obtained.

Table 7 - Independent variables and responses optimal results

\begin{tabular}{|c|c|c|c|c|c|c|c|}
\hline $\begin{array}{c}\text { Fibre / } \\
\text { binder } \\
(\mathrm{w}: \mathrm{w})\end{array}$ & $\begin{array}{c}\text { Pressure } \\
\left(\mathrm{kg} / \mathrm{m}^{2}\right)\end{array}$ & $\begin{array}{c}\text { Temperature } \\
(\mathrm{oC})\end{array}$ & $\begin{array}{c}\text { Density } \\
\left(\mathrm{kg} / \mathrm{m}^{3}\right)\end{array}$ & $\begin{array}{c}\text { Water } \\
\text { Absorption } \\
(\%)\end{array}$ & $\begin{array}{c}\text { Tensile } \\
\text { strength } \\
\left(\mathrm{N} / \mathrm{m}^{2}\right)\end{array}$ & $\begin{array}{c}\text { Thermal } \\
\text { conductivity } \\
(\mathrm{W} / \mathrm{mK})\end{array}$ & Desirability \\
\hline $1: 1$ & 500 & 92 & 151.50 & 9.05 & 16.90 & 0.106 & 0.62 \\
\hline $1: 2$ & 100 & 30 & 204.40 & 4.74 & 16.80 & 0.206 & 0.60 \\
\hline $1: 1$ & 500 & 30 & 163.30 & 13.70 & 13.40 & 0.122 & 0.58 \\
\hline $1: 1$ & 500 & 30 & 144.42 & 16.60 & 12.8861 & 0.087 & 0.57 \\
\hline $2: 1$ & 500 & 100 & 151.81 & 17.70 & 21.13 & 0.050 & 0.55 \\
\hline
\end{tabular}

From Table 7, parameters in No1 was used in reproducing the piliostigma thonningii ceiling board composite for validation. The predicted results gave a minimal error difference when compared with the experimental results as shown in Table 8.

Table 8 - Validated results

\begin{tabular}{|c|c|c|c|c|c|c|c|c|c|c|}
\hline $\begin{array}{c}\text { Fiber } / \\
\text { binder } \\
(\mathrm{w}: \mathrm{w})\end{array}$ & $\begin{array}{c}\text { Press } \\
\left(\mathrm{kg} / \mathrm{m}^{2}\right)\end{array}$ & $\begin{array}{c}\text { Temp } \\
\left({ }^{\circ} \mathrm{C}\right)\end{array}$ & \multicolumn{2}{|c|}{ Density $\left(\mathrm{kg} / \mathrm{m}^{3}\right)$} & \multicolumn{2}{c|}{$\begin{array}{c}\text { Water } \\
\text { Absorption } \\
(\%)\end{array}$} & $\begin{array}{c}\text { Tensile strength } \\
\left(\mathrm{N} / \mathrm{m}^{2}\right)\end{array}$ & \multicolumn{3}{|c|}{$\begin{array}{c}\text { Thermal } \\
\text { Conductivity } \\
(\mathrm{W} / \mathrm{mK})\end{array}$} \\
\hline \multicolumn{2}{|c|}{} & & $(\mathrm{P})$ & $(\mathrm{Ex})$ & $(\mathrm{P})$ & $(\mathrm{Ex})$ & $(\mathrm{P})$ & $(\mathrm{Ex})$ & $(\mathrm{P})$ & $(\mathrm{Ex})$ \\
\hline $1: 1$ & 500 & 92 & 151.50 & 151.92 & 9.05 & 9.03 & 16.90 & 16.90 & 0.106 & 0.09 \\
\hline
\end{tabular}

\section{CONCLUSIONS AND RECOMMENDATIONS}

The following conclusions were drawn from the 15 experimental runs results for the study.

1. The board's density increases as the ratio of the binder to the fibre increases. The boards have correspondingly lower densities compared to the standard boards

2. The board's percentage water absorption, some results fall within the conventional standard board values made from organic materials.

3. The boards recorded the lowest tensile strength ranging between $9.8 \mathrm{~N} / \mathrm{m}$ and $19.32 \mathrm{~N} / \mathrm{m}$.

4. The piliostigma thonningii fibre boards have potentials for use as thermal insulation; the values fall within the requirement.

The following recommendations are made for further work:
The mechanical and thermal properties such as creep test, compressive strength, modulus of rupture, modulus of elasticity and thermal resistivity of the piliostigma thonningii fibre boards should be investigated.

The boards should be produced by the application of catalysts (initiator and accelerator) and evaluate their properties.

Since the boards were produced from organic materials, there is a need to examine the effect of insect attack which is mostly associated with organic products.

\section{ACKNOWLEDGEMENT}

We sincerely Acknowledge Abubakar Tatari Ali Polytechnic, Bauchi for providing the fund for the research through the Academic Staff Training and Development of Tertiary Education Trust Fund of the federal government of Nigeria. 


\section{REFERENCES}

1. Abdullahi, I., \& Umar A. A. (2010). Potentials of unsaturated polyester ground nut shell as material in building industry. Journal of Engineering and Technology, 5, 78-84.

2. ASTM International. (2012). Standard Test Methods for Evaluating Properties of Wood-Base Fiber and Particle Panel Materials (ASTM D1037-12). doi: 10.1520/d1037-12

3. ASTM International. (2016). Standard Test Method for Dimensions and Density of Preformed Block and Board-Type Thermal Insulation (ASTM C303-10(2016)e1). doi: 10.1520/C0303-10R16E01

4. ASTM International. (2018). Standard Test Method for Water Absorption of Plastics (ASTM D57098(2018)). doi: 10.1520/D0570-98R18

5. Bledzki, A. (1999). Composites reinforced with cellulose based fibres. Progress in Polymer Science, 24(2), 221-274. doi: 10.1016/s0079-6700(98)00018-5

6. British Standard Institute. (2018). Methods of test for soils for civil engineering purposes. Chemical and electro-chemical testing (BS 1377-3:2018). Retrieved from https://shop.bsigroup.com/en/ProductDetail/?pid=000000000030351284

7. Chidumayo, E. Growth of Bauhinia thonningii Trees and Saplings over a Decade in a Savanna in Zambia: Interactions of Climate, Fire and Source of Regeneration. Journal of Tropical Ecology, 24(4), 407-415.

8. Dagwa, I. M., Builders, P. F., \& Achebo, J. (2012). Characterization of Palm Kernel Shell Powder for use in Polymer Matrix Composites. International Journal of Mechanical and Mechatronics Engineering, 12(4), 88-93

9. Ekpunobi, U., Ohaekenyem, E., Ogbuagu, A., \& Orjiako, E. (2015). The Mechanical Properties of Ceiling Board Produced from Waste Paper. British Journal of Applied Science \& Technology, 5(2), 166172. doi: 10.9734/bjast/2015/11627

10. JSTOR. (2019). Bauhinia thonningii. Retrieved March 1, 2019 , from https://plants.jstor.org/compilation/bauhinia.thonningii?searchUri=

11. Jústiz-Smith, N. G., Virgo, G. J., \& Buchanan, V. E. (2008). Potential of Jamaican banana, coconut coir and bagasse fibres as composite materials. Materials Characterization, 59(9), 1273-1278. doi: 10.1016/j.matchar.2007.10.011

12. Klyosov, A. A. (2007). Wood Plastic Composite. New Jersey: John Wiley \& Son Inc.

13. Nemli, G., \& Aydın, A. (2007). Evaluation of the physical and mechanical properties of particleboard made from the needle litter of Pinus pinaster Ait. Industrial Crops and Products, 26(3), 252-258. doi: 10.1016/j.indcrop.2007.03.016

14. Oehlert, G. (2010). A First Course in Design and Analysis of Experiments. Minnesota: University of Minnesota.

15. Panyakaew, S., \& Fotios, S. (2011). New thermal insulation boards made from coconut husk and bagasse. Energy and Buildings, 43(7), 1732-1739. doi: 10.1016/j.enbuild.2011.03.015

16. Schwartz, M. M. (1992). Composite Materials Handbook (2nd ed.). New York: McGraw-Hill.

17. Shaffer, J., Ashok, S., Antonovich, S. A., Sanders, Th. H., \& Warner, S. (1999). The Science and Design of Engineering Materials (2nd ed.). New York: WCB/McGraw-Hill.

18. Tangjuank, S., \& Kumfu, S. (2011). Particle Boards from Papyrus Fibers as Thermal Insulation. Journal of Applied Sciences, 11(14), 2640-2645. doi: 10.3923/jas.2011.2640.2645 